\title{
Why be just? \\ The problem of motivation in Hegel and Rawls
}

\author{
CARSTEN FOGH NIELSEN and EMILY HARTZ
}

\begin{abstract}
:
At the heart of any theoretical problem of justice, lies the problem of motivation: even if we could conceive of a way to develop a comprehensive system of just laws, and even if we could rationally believe in the justice of these laws, how could we ever ensure that we - or any-one else - would be motivated to abide by them? By unearthing how the problem of motivation sways canonical discussions of justice, the article brings forth intrinsic similarities and differences in these discussions that are often overlooked in the literature. In particular, the article highlights intrinsic similarities in the analysis of the concept of justice in two central works that belong to the continental and the analytic tradition respectively and are otherwise rarely discussed together: Hegel's Outlines of the Philosophy of Right and Rawls' A Theory of Justice.
\end{abstract}




\section{Why be just?}

\section{The problem of motivation in Hegel and Rawls}

In this paper we focus on one of the oldest and most basic problems in political theory, the problem of how and why free individuals should subject themselves to the rule of the political community, also known as 'the problem of motivation.'

Historically, the problem of motivation has been articulated in many different ways. ${ }^{1}$ A closer look at these different articulations reveals that the problem of motivation is not really one problem, but rather a family of distinct but intimately related problems concerning the basic relation between particularity and universality and between motivation and justification. ${ }^{2}$ In fact, or so we will argue, the family of problems that constitute the problem of motivation can be seen to structure discussions of justice across historical and theoretical divides. Therefore, a better conceptual understanding of the problem of motivation helps us categorize similarities and differences across these divides. In particular, such conceptual clarification helps us understand - and possibly bridge the divide between continental and analytical approaches to political philosophy and philosophy of law. This defines the underlying aim of the following discussion of the problem of motivation.

We start by suggesting a five-fold analytic through which to understand the different versions of the problem of motivation. We then apply this analytic to categorize classical philosophical solutions to the problem. This paves the conceptual ground for analyzing two central texts in political philosophy namely Hegel's Outlines of the Philosophy of Right and Rawls' A Theory of Justice. These two texts are paradigmatic texts in the continental and the analytical tradition respectively and have both been subject to extensive analysis. However, the two texts are rarely discussed together. By using the problem of motivation to bring these two texts into dialogue 
we therefore hope to draw attention to important differences and similarities between these two traditions that are otherwise easily overlooked. ${ }^{3}$

\section{The problem of motivation: conceptual distinctions}

At the most basic level the problem of motivation can be viewed from the perspective of the individual as a problem concerning the intelligibility, rationality, and desirability of any set of social, political or juridical norms. This perspective on the problem of motivation arises when an individual member of a political community asks: "Why be just?" What she is requesting is an answer that would provide her with good reasons for continuing to submit herself to the collective rule of the political community. ${ }^{4}$

Within this individualistic perspective, there are at least two distinct versions of the problem of motivation. ${ }^{5}$ First, the problem can be interpreted as an instrumental problem concerning selfinterest, that is as a question of why and to what extent it is in the individual's best interest to become a member of the political community and to acknowledge the authority of the principles of justice that governs that community. "What do I get out of being just?” the individual might ask. "How does justice facilitate my interests?" Taken in this sense the question concerns the motivational basis for accepting and/or rejecting the basic requirements of justice. ${ }^{6}$

Alternatively and second, the problem of motivation can be interpreted in normative terms, as a problem concerning the normative justifiability of the principles and norms of the political community. In this case, what the individual wants to know is whether and why she ought to become a member of the political community; whether and why she ought to acknowledge the authority of the community's principles of justice. ${ }^{7}$ Why are these principles normatively binding for her? ${ }^{8}$ 
Both these versions of the problem of motivation start from the perspective of the individual. But the problem can also be viewed from the perspective of the political community. The continued existence of any political community depends on the willingness of its members to act in accordance with its basic principles of justice. If the behavior of a substantial proportion of the members of a political community fails to conform to the principles of justice structuring that community, the community will be inherently unstable. From the community-perspective the basic problem is thus that of ensuring that (a sufficient proportion of) the members of a political community adhere to the community's principles of justice. This perspective gives rise to at least four separate versions of the problem of motivation:

First, there is a purely instrumental version according to which it is irrelevant why people comply with the principles of justice. All that matters is that they do so. Whether people adhere to these principles out of self-interest (because they are afraid of being punished or because they believe it serves their interests in other ways), because of unreflective habit, or because they regard these norms as inherently valuable is regarded as irrelevant as long as the stability of the community is maintained. ${ }^{9}$

Second, there is what we might call an instrumental-normative version. According to this version the stability of the political community cannot be sustained in the long run unless most, if not all, members of the community freely acknowledge and respect the legitimacy of the basic principles. From this perspective, the problem of motivation becomes a question of whether and how to get people to freely and willingly endorse and be motivated by their political community's basic principles. This approach still has a strongly instrumental dimension (the ultimate aim is to ensure the stability and continued existence of the community), but is based upon a much more substantial normative view of the value and importance of freely acknowledging the legitimacy of the basic principles of justice. ${ }^{10}$ 
Third, the community-perspective also gives rise to a fully normative version of the problem of motivation. This version of the problem arises when we continue the move from external behavior to internal motivation initiated by the previous instrumental-normative version of the problem. On the fully normative account political subjects should ideally be motivated to act in accordance with the principles and norms of their political community not because of fear or selfinterest, or because of tradition and habit, but because they truly view these principles as valuable, and worthy of respect. In contrast to the instrumental-normative account, this version of the problem of motivation arises not from a purely instrumental concern with the stability of a community, but from a substantive normative belief; the belief that free and autonomous compliance with and endorsement of the principles of justice constitutes the most adequate and proper (moral) motivation to be just. ${ }^{11}$

Finally the two latter versions of the problem of motivation both point toward what we might call the liberal-perfectionist version of this problem. If free and willing compliance with the basic principles of justice is an important means to solving the motivation problem and/or an intrinsically valuable end in itself, then this raises the question of how to develop and promote the human capacity for autonomous choice. This is a liberal-perfectionist problem because it takes freedom to be a, if not the basic political value (hence "liberal”), while simultaneously viewing freedom as not simply the absence of (external) constraints on the will, but as a positive human capacity for autonomy, ${ }^{12}$ which human beings and political communities have a duty to develop and nurture (hence “perfectionism”). ${ }^{13}$ From a liberal perfectionist perspective, the problem of motivation thus concerns the conditions for realizing the human potential for (moral) freedom. The problem is not primarily a problem of aligning individual and collective needs and desires, but rather a problem of how to organize the laws and institutions of a society in such a way that 
individuals can and may develop their capacity for autonomy in the most suitable and adequate way.

\section{The problem of motivation: standard solutions}

Historically there are at least three distinct ways to formulate and solve the problem of motivation. First, we have what we might call the Hobbesian solution. ${ }^{14}$ Hobbes famously takes human self-interest to be both the most basic and the most important source of human motivation as well as the primary cause of human conflict and strife. According to Hobbes, most people desire the same types of things (the basic means for survival, honour, riches. security) and because social and natural resources are limited human beings are necessarily in competition with one another. In light of this, only the introduction of a system of binding social norms can prevent this competition from degenerating into a merciless “warre of every man against every man”. ${ }^{15}$

Hobbes proposes a two-step procedure for getting people to agree to such a system, in which both steps are based on appeals to rational self-interest. Hobbes first argues that being a member of a political community structured by certain basic principles of justice enables a much more efficient way of satisfying individual desires and interests than other available alternatives. This is how selfinterested and rational individuals are convinced that they should leave the state of nature and band together in a political commonwealth. ${ }^{16}$

Second, Hobbes argues that the only way to successfully cope with and contain the inherent self-interest of human nature is to establish a political community in which violations of the principles of justice are so severely penalized that it will (almost) never be in the interest of particular individuals to even contemplate violating these norms. The primary function of political authority in the Hobbesian state is therefore to check individual self-interest. ${ }^{17}$ 
One obvious problem with the Hobbesian solution is that it does not resolve the conflict between self-interest and justice; it merely represses it. Citizens in the Hobbesian state retain their basic nature: they are just as motivated by self-interest as individuals in the (hypothetical) state of nature. If it serves their own interest, and if they are reasonably sure they can do so without being caught, citizens in the Hobbesian state have little or no reason not to violate the social norms laid down by the sovereign. This makes the Hobbesian state vulnerable to all kinds of free-rider problems - problems which undermine the effectiveness and stability of the system of social norms, ultimately threatening the stability of the political community itself. At the very least it thus seems that the Hobbesian model needs to be supplemented by other ways of solving the problem of motivation.

Locke $^{18}$ presents a related but slightly different solution to the problem of motivation. Locke agrees with Hobbes that being a member of a political community structured by certain basic principles of justice advances the pursuit of individual self-interest by enabling more efficient ways of satisfying individuals' desires than other available alternatives. One fundamental difference between Locke's approach and Hobbes' is that the former views the claims of self-interest and the requirements of justice as being more in alignment than the latter. According to Locke people are not motivated solely by purely self-interested wants and desires. They are motivated also by concern for certain others: for parents, children, spouses, relatives, and friends. ${ }^{19}$ As Locke sees it the principles of political justice draw upon and utilize these natural social bonds. Political society thus arises out of and is founded upon pre-existing forms of human relationships, even as it is supplemented and strengthened by enlightened self-interest. In this context, the conflict between individual self-interest and the requirements of the political community is not nearly as stark as envisioned by Hobbes. 
That said situations might very well arise in which the best way to serve my own particular interests or the interest of those nearest and dearest to me is to take unjust advantage of others by violating or abusing the very principles on which the political community is founded. For this reason the Lockean approach faces the same free-rider problems as the Hobbesian approach.

A third distinct solution to the problem of motivation is what we will call the developmental approach. Both the Hobbesian and the Lockean approach focus on how society can be structured to minimize the inherent conflict between individuals' self-interest and political justice. The developmental approach on the other hand focuses on how the basic motivational structure of individuals can be gradually transformed, so that this structure reflects and endorses the broader moral and political values of the political community to which these individuals belong. ${ }^{20}$

Proponents of the developmental approach contend that human beings are not simply thrown into the world equipped with fully formed interests, desires, and needs, which the political community then has to either repress or facilitate. On the contrary, our basic motivational make-up, the interests that move us to action, are not something fixed; they are constantly being reshaped and transformed by the social and political structures of the community.

On this view, the apparently intractable conflict between the claims of self-interest and the requirements of justice is not in fact a necessary and unavoidable feature of human existence. It is rather a problem, which may conceivably be resolved through a gradual process of socially mediated moral cultivation. The basic principles of justice, so the argument goes, need not be perceived as an external constraint on the pursuit of individual self-interest. With the proper sort of social and cultural formation these principles can instead become an intrinsic part of the individual's own understanding of the good and thus something he or she endorses and values. 
The developmental approach to the problem of motivation has a long and distinguished pedigree within the history of political and moral philosophy. Plato, Aristotle and Rousseau thus all believed that any plausible and coherent theory of justice must include an account of how individuals come to be motivated by (their understanding of) the basic principles of justice. In the rest of this paper we will argue that Hegel and Rawls also belong to this tradition. We will do so with special attention to their most famous and influential contributions to political philosophy: Hegel's Outlines of the Philosophy of Right and Rawls' A Theory of Justice.

\section{Hegel's approach to the problem of motivation}

For Hegel, the problem of motivation is intrinsically linked to the question of how to understand, think about, and actualize freedom. Hegel believes that different conceptions of freedom give rise to different kinds of motivational challenges. His multi-layered discussions of freedom in Outlines of the Philosophy of Right are thus structured by and intimately entwined with discussions of various iterations of the problem of motivation.

The first part of the Outlines of the Philosophy of Right, Abstract Right [Das Abstrakte Recht], addresses what we might call 'personal freedom'; freedom understood as an individual's basic capacity to choose freely among given ends. The second part, Morality [Die Moralität], discusses 'moral freedom'; a moral subject's capacity to determine him- or herself independently of his or her particular needs and desires. The third and final part Ethical Life [Die Sittlichkeit] discusses ‘social freedom'; freedom conceived as identifying with and being a valuable and valued part of the basic social structures of modern society: the family, civil society and the modern state. ${ }^{21}$

Abstract Right, takes its starting-point in the conception of freedom which defines classical liberalism, what we nowadays might call libertarianism. For the libertarian, individual freedom 
consists in the ability and possibility of choosing and acting freely, that is; choosing and acting unconstrained by external impediments. Hegel calls this form of freedom "arbitrariness [Willkür]” or 'freedom of choice' 22 and appeals to it in his definition of personhood. For Hegel a person is a particular individual capable of free choice. ${ }^{23}$ According to Hegel, the purpose of a juridical order is to enable the expression of personhood by creating a normative sphere in which human beings can freely and securely pursue whatever self-interested aims they happen to have. The juridical order does this primarily by establishing impartial legal norms which makes possible the existence and transference of private property, ${ }^{24}$ and by creating legal safeguards protecting individual freedom of choice against incursions and violations from other people. ${ }^{25}$

Unfortunately the libertarian conception of freedom quickly gives rise to one of the basic versions of the problem of motivation outlined above. Making individual freedom of choice a social reality seems to necessarily presuppose or require a number of social structures and institutions, most importantly an impartial juridical order. Such institutions necessarily impose restrictions and limitations on what individuals can and may legitimately do in pursuit of their personal, selfinterested aims. The problem of motivation thus arises as soon as someone motivated by the libertarian conception of freedom begins to ask, why he or she should accept any external restrictions on individual freedom of choice. If legal requirements and norms limit what an individual may legitimately do in pursuit of her self-interest, and if self-interest is her primary source of motivation, what could then possibly motivate her to accept such legal requirements?

Hegel argues that this problem does not mean that the concept of abstract right is inherently deficient. It rather points toward the need for a broader and more complex understanding of what freedom means. Abstract Right is undoubtedly important, but freedom of choice, the notion of freedom on which Abstract Right is founded, is just one aspect of what human freedom can and should mean. Hegel believes that an exclusive focus on Abstract Right as a necessary precondition 
for the libertarian notion of individual freedom hides from view another important precondition for this form of freedom, namely the need for and right to recognition. For Hegel, the capacity for free choice, which defines personhood and underpins the notion of Abstract Right, is never a mere matter of fact. It is not something human beings possess simply in virtue of being human. Personhood for Hegel presupposes an act, a choice; the choice to recognize and respect both my own and other people's capacity for free choice. It is this choice, which is reflected and made into concrete reality through the establishment of a juridical order of Abstract Right. The right to be recognized as a person, as someone who possesses freedom of choice, is - so Hegel argues — implicitly presupposed in every legal claim and is therefore an implicit precondition for Abstract Right. $^{26}$

Every person's rightful demand to be recognized as a person, as a locus of free choice, turns out to be a natural and inevitable presupposition for the classical liberal attempt to realize freedom of choice through the establishment of an abstract legal system. Thus, although Hegel initially seems to embrace the libertarian notion of individual freedom of choice, the individual-instrumental version of the problem of motivation eventually leads him to conclude that the libertarian viewpoint necessarily points beyond individuality; that individual freedom of choice implies a form of universality as its necessary precondition. Differently put, consistency of thought leads the libertarian to the conclusion that individual freedom of choice can only be fully realized if that choice is based on the recognition of the equal freedom of everybody. ${ }^{27}$

According to Hegel adopting such a universal viewpoint, what he calls Morality, dissolves the contradictions inherent in the classic libertarian notion of abstract right. Unfortunately this viewpoint simultaneously introduces a new set of questions and problems. As Hegel famously puts it: the moral point of view (which Hegel, perhaps unfairly, identifies with Kant's moral philosophy) ultimately reduces itself to "an empty formalism and the science of morals to the preaching of duty 
for duty’s sake.” ${ }^{28}$ By leaving individuality and particularity behind and focusing solely on the universal form of the moral will, morality becomes too formal, too empty, to yield any concrete determination of duty or provide any reliable guidelines for what ought to be done. This once again brings us back to the problem of motivation. It turns out that Hegel's attempt to solve the libertarian version of the problem of motivation produces an even more radical version of this very problem: since morality leaves everything particular and substantial behind, it proves incapable of giving any reasons for its normative authority. Morality cannot answer the question of why we as individuals should accept and be motivated to act upon its universal requirements, because we cannot even identify what these requirements are, or what they ask of us.

The re-emergence of the problem of motivation-inherent in the moral viewpoint as articulated by Hegel —is what motivates the turn to Ethical Life in the third part of Outlines of the Philosophy of Right. The explicit aim of this final part of Hegel's work is to show how the particular (which is the focus of Hegel's analysis of Abstract Right) can be integrated with the universal (which is the focus of Hegel's analysis of Morality), so that the inherent problems and deficiencies of both these two positions can be resolved.

The move from Morality to Ethical Life represents a fundamental change of direction in Hegel's discussion of the problem of motivation. As we have just seen the two first parts of Outlines of the Philosophy of Right approaches this problem from the perspective of the individual, and asks how and why the individual should comply with and be motivated by principles, which transcend his or her particular interests and values. The third part of the book, the section on Ethical Life, changes the discussion in at least two ways. First of all the discussion moves from an explicitly individualistic to an explicitly communal or social perspective, where the individual is viewed as always-already a member of numerous social groups and institutions. Secondly the discussion now turns to a liberal-perfectionist version of the problem of motivation. More precisely the section on 
Ethical Life proposes an explicitly developmental response to this question, which combines the focus on individual rights that structured the discussion of Abstract Right, with the emphasis on universality that structured the discussion of Morality:

... the universal does not prevail or achieve completion except along with particular interests and through the cooperation of particular knowing and willing; and individuals do not live as private persons for their own ends alone, but in the very act of willing these they will the universal for the sake of the universal and their activity is consciously aimed at the universal end. ${ }^{29}$

In Ethical Life Hegel responds to the problem of motivation by explicating the implicit normative structures inherent in and distinctive of three important social institutions of the modern world: the nuclear family, civil society (the free market and the institutions associated with the production and distribution of goods), and the state. Hegel's idea is that participation in these three social institutions slowly but surely transform the self-interested inclinations and ego-centered desires of particular individuals enabling them to gradually adopt a more universal point of viewone that remains the individual's own while simultaneously representing and expressing universal concerns. ${ }^{30}$

For Hegel, the modern nuclear family is an essential part of this transformative process. ${ }^{31}$ According to him, the essential bond that unites the members of a family is love, and love implies letting one's own particularity be defined through- and constituted by others. ${ }^{32}$ Hegel thus argues that being a member of a family therefore necessarily transforms and expands a person's immediate self-interest.

In civil society the satisfaction of my particular interests are also necessarily dependent on others, but in a very different way. In modern society, Hegel claims, everybody is compelled to 
participate in and contribute to an impersonal 'system of needs' which he identifies as “[t]he infinitely complex, crisscross, movements of reciprocal production and exchange, and the equally infinite multiplicity of means therein employed." 33 This system not only creates a market based on the mutual interdependence of strangers, but also introduces a number of new, socially mediated needs and wants, which can only be satisfied by actively participating in this system. ${ }^{34}$ According to Hegel, it is through our participation in this social production and distribution of goods and services that we come to define and express our individuality. This introduces an irreducible, and potentially universal, social dimension to individuality: we are, or rather become, the particular human subjects we strive to be, in and through our participation in a social order, which necessarily transcends our particular individuality. ${ }^{35}$

As a member of a family and as a participant in the system of needs my individual subjectivity is always-already socially mediated, always-already intimately intertwined with the life of others. Reflection on what it means to be a member of a family and to participate in the system of needs thus reveals that my interests are not necessarily opposed to or in conflict with the needs and desires of others, but are in fact based upon and made possible through the contribution of both family and strangers.

However, neither the family nor civil society on their own provides an adequate and complete solution to the liberal-perfectionist version of the problem of motivation and the question of how to develop the human capacity for freedom. The family only provides a limited transcendence of particularity because there my individuality is inescapably bound up with the interests of particular others, namely the members of my family. In civil society on the other hand my individuality is dependent upon and formed by the actions and activities of a multitude of unknown others: my co-participants in the system of needs, the producers and distributors of the goods and services which I myself need. But my participation in this system is primarily motivated 
by (enlightened) self-interest, not by moral or ego-transcending reasons. ${ }^{36}$ To resolve the liberalperfectionist problem we need yet another potentially transformative social structure; a structure in and through which particular individuals can learn to be motivated not merely by concern for their loved ones or by enlightened self-interest but by impartial and universal moral concerns. This, in Hegel's analysis, is what necessitates the third and final section of Ethical Life: his analysis of the modern state. ${ }^{37}$

Hegel believes that the modern state makes possible the fullest and deepest realization of individual freedom. The state provides the necessary political and institutional framework through which both Abstract Right, the family, and civil society are able to function properly. Because the state transcends and is necessarily presupposed by all of these particular normative spheres it provides citizens with an understanding and appreciation of those basic, common norms, which ultimately enables them to express and pursue their individuality:

The principle of modern states has prodigious strength and depth because it allows the principle of subjectivity to progress to its culmination in the selfsufficient extreme of personal particularity, and yet at the same time brings it back to the substantial unity and so maintains this unity in the principle of subjectivity itself. ${ }^{38}$

In Hegel's idiom, the state is "objective spirit." ${ }^{39}$ The state is an objective social institution in and through which human beings gradually come to acknowledge and identify with the basic normative structures, which define the modern world. ${ }^{40}$ In this way the state enables a fundamental integration of individuality and universality, of the self-interested concerns of particular individuals and the universal aspirations of disinterested justice. ${ }^{41}$

According to Hegel it is thus through our participation in the social institutions of the 
modern world, the legal system, the system of morality, the family, civil society and the modern state as described in the Outlines of the Philosophy of Right, that the problem of motivation is gradually solved. Not by simply redirecting self-interest in directions more conducive to communal values and norms, but by transforming human nature so that communal, even universal, values and norms, gradually become intrinsically motivating and aspects of our own, particular understanding of the good.

\section{Rawls' approach to the problem of motivation.}

At first glance Rawls's A Theory of Justice seems an unlikely place to look for a similarly developmental solution to the problem of motivation. After all a developmental approach seeks to incorporate concrete social and historical factors in political theory, something which do not immediately seem to sit well with the explicitly abstract, universal, and ahistorical account of political justice Rawls presents in A Theory of Justice. ${ }^{42}$

However, a closer reading of A Theory of Justice quickly reveals that whereas the first two parts of the book clearly are dedicated to developing an ahistorical and (potentially) universal conception of political justice, the third part of the book has quite another focus. Rawls' aim in the third part is to argue that the basic social structures of modern liberal democratic states both can and will transform the psychological constitution of their citizens, so that a concern for basic principles of justice gradually becomes a crucial and integral part of the self-understanding and conception of the good of these citizens.

Furthermore, Rawls' explicit motivation for the discussion in this part of the book seems to be worries arising from some version of the problem of motivation. More precisely Rawls believes that the principles of justice, presented and defended in the first two parts of A Theory of Justice, 
must be shown to be psychologically realistic; they must be principles which members of a just society would in fact be motivated to acknowledge and endorse. Otherwise, he readily admits, a society based on these principles would be inherently unstable. ${ }^{43}$

For Rawls the problem of motivation is thus fundamentally a problem of social stability. ${ }^{44}$ This problem arises because of the argumentative structure of A Theory of Justice. The main function of the original position as developed in the first and second part of the book is to provide a framework for rationally discussing, deliberating on and evaluating different conceptions of justice, and to thereby reach an informed decision about the viability and justifiability of these conceptions. ${ }^{45}$ In these sections of the book Rawls seems to argue that questions concerning motivation can be temporarily put aside, at least when discussing the purely procedural derivation of the fundamental principles of justice.

In the third part of the book however, Rawls makes it quite clear that these questions cannot be permanently dismissed. Whether ordinary people in real life circumstances will actually be motivated to adopt and endorse the basic principles of justice arrived at in the original position may not be of immediate importance for the principled discussions taking place behind the hypothetical veil of ignorance. But it is of importance at the level of practical applicability. If the basic principles of justice are inherently at odds with the motivations and interest of ordinary, fully fleshed, real-life people, then a society based on these principles will be fundamentally unstable. And Rawls is quite clear that this fact is something which his political theory at some point has to take into consideration:

It is evident that stability is a desirable feature of moral conceptions. Other things equal, the persons in the original position will adopt the more stable scheme of principles. However attractive a conception of justice might be on 
other grounds, it is seriously defective if the principles of moral psychology are such that it fails to engender in human beings the requisite desire to act upon it. ${ }^{46}$

The third part of A Theory of Justice is Rawls' explicit attempt to address this problem. More precisely it is Rawls' attempt to show that a well-ordered society — a society "designed to advance the good of its members and effectively regulated by a public conception of justice" — will also be a stable society. ${ }^{47}$ To do this, Rawls outlines a developmental account of how members of a wellordered society gradually come to accept and endorse basic principles of justice which closely match those articulated in the first two parts the book. To use Rawls' own words: The third part of A Theory of Justice attempts to explain how members of a well-ordered society acquire a "sense of justice". ${ }^{48}$

Much like Hegel's discussion of Ethical Life, Rawls' developmental approach takes its starting-point in an analysis of the bonds of love, which define the modern nuclear family. But where Hegel argues that familial love expands and alters the basic interests of every member of the family, Rawls specifically focuses on how parental love transforms the interests and desires of the child. According to Rawls, expressions of parental love are crucial for the child's moral development: "when the parent's love of the child is recognized by him on the basis of their evident intentions, the child is assured of his worth as a person." ${ }^{49}$ Through this process, the child gradually comes to assess her own actions according to the norms of the parent. ${ }^{50}$ In this way the love between parent and child gives rise to a "morality of authority", where the judgments of trusted authorities such as parents gradually become intrinsic to the child's assessment of her own worth and the worth of her actions. ${ }^{51}$ Such a morality of authority provides a first and limited example of how values and norms, which do not necessarily cohere with the immediate self-interest of a child, can still become an internalized part of the child's motivational system. ${ }^{52}$ 
However, such a morality of authority does not yet constitute a fully developed sense of justice. For this, a further developmental step is needed, namely the development of what Rawls calls a "morality of association." 53 Rawls finds the source of this wider moral perspective in the many associations and cooperative ventures, which members of a well-ordered society typically engage in: school, sports clubs, neighbourhood associations, games, plays, and so forth. Once again there are clear similarities between Rawls' discussion of how participation in such interpersonal associations gradually transforms our motivational make-up and Hegel's analysis, in particular Hegel's discussion of civil society. One key difference however is that where Hegel's analysis focused on the economic system which produces and distributes goods and services, Rawls' analysis primarily focuses on the many non-economic cooperative practices and activities, which in most modern societies constitute the main part of "civil society."

Rawls argues that by participating in and being a member of such cooperative associations we gradually come to view and evaluate ourselves and our actions not simply by means of our more or less self-interested desires, but also, perhaps even primarily, by the expectations and evaluative frameworks, which define our roles in and contributions to these cooperative schemes. ${ }^{54}$ Furthermore, even if we initially chose to participate in a certain association for the sake of personal gain, the cooperative nature of the association will (if not always, then at least sometimes) gradually transform our view of the value of the association. We come to value our cooperative associates not merely for their contribution to the satisfaction of our own, particular needs, but as partners in a common practice. In Rawls’ words, we come to praise "the virtues of a good student and classmate” or "the ideals of a good sport and companion." 55 In this way our social experiences, our participation in different social practices and associations, broaden and expand our conception of what has value, what matters to us and what we ultimately desire beyond our own narrow perspective. ${ }^{56}$ 
However, a morality of association is not the developmental endpoint for Rawls. Rawls believes that in a well-ordered society the morality of association will typically develop into a morality of principles, a broader evaluative framework in which each individual identifies with and is motivated by a sense of justice, which incorporates the basic and universal principles of justice governing liberal democratic societies. This motivational transformation occurs as we, through our involvement in cooperative associations of different kinds, gradually become aware of and learn to appreciate and value the basic communal ideals and principles which enable and structure the basic social framework within which these associations function. ${ }^{57}$ At this point in Rawls developmental story we are thus no longer motivated solely by our own interests or desires, nor by the interest and desires of our family, friends and associates, but also by the fundamental social values and norms which at the most basic level structure our common life together.

Importantly, Rawls does not propose that every particular cooperative venture or association must explicitly endorse or express such basic principles of justice. Rawls readily acknowledges that the aims of most associations are typically far less abstract and much more mundane, like supporting the local football team, enhancing the color diversity in the Icelandic horse breed or organizing philosophy talks at the local community college. But Rawls does think that associations, institutions and practices within a just and well-ordered society will ultimately have to formulate and realize their aims in accordance with this society's basic and (more or less) publicly acknowledged conception of justice. This in turn implies that our participation in organizations, clubs, schools etc. gradually accustoms us to either implicitly or explicitly take account of these basic principles in our everyday life. ${ }^{58}$

Rawls thus claims that "the morality of association quite naturally leads up to a knowledge of the standards of justice”, and that "[w]e develop a desire to apply and to act upon the principles of justice once we realize how social arrangements answering to them have promoted our good and 
that of those with whom we are affiliated. ${ }^{59}$ In due course we thus come to appreciate the ideal of just human cooperation. ${ }^{60}$

According to Rawls the gradual cultivation and transformation of the self, which takes place in a well-ordered and just society will thus typically lead to a certain congruence between the interests of the individual and the requirements of justice. In a just and well-ordered society the individual and particular conceptions of values and norms, which guide and structure much of our own everyday life, will, so Rawls believes, gradually come to align with the more general, potentially universal, principles of justice, which guide and structure our common life with others. If successful, this developmental process will eventually result in a situation where:

Ethical norms are no longer experienced merely as constraints, but are tied together into one coherent conception. The connection between these standards and human aspiration is now comprehended, and persons understand their sense of justice as an extension of their natural attachments, and as a way of caring about the collective good. ${ }^{61}$

This developmental account is Rawls' solution to the problem of motivation. His account argues that in a just and well-ordered society the interest of the individual and the interest of the community will be intrinsically linked in such a way that radical discrepancy between the individual's pursuit of a good life and society's basic norms and principles is, if not ruled out, then at least reduced to a point of little significance. In other words: Rawls believes he has shown that the principles of justice arrived at in the original position can be successfully implemented in real life in such a way that a society based on these principles would be fundamentally stable.

\section{Comparison and discussion of Hegel's and Rawls' approach to the problem of motivation}


We have argued that both Hegel and Rawls present a developmental solution to the problem of motivation. However, despite a number of similarities between Hegel's and Rawls' proposed solutions there are also many crucial and important differences. In this section we investigate some of the most interesting and crucial convergences and divergences between Hegel's and Rawls' approaches to the problem of motivation.

The most important parallel between Outlines of the Philosophy of Right and A Theory of Justice is that both Hegel and Rawls explicitly deny that there is a necessary conflict between particularity (individual self-interest) and universality (the social requirements of justice and morality). It is this assumption that both motivates and enables their developmental approach to solving the problem of motivation. And while they arrive at the developmental approach in different ways both Hegel and Rawls ultimately argue that in just and well-ordered societies people will gradually learn to acknowledge, appreciate, and identify with certain communal principles of justice — principles which structure and are embodied in the basic social institutions such as the family, cooperative associations, and the like. Hegel and Rawls also both claim that the modern state approximates such a just and well-ordered society.

A second important parallel between Hegel and Rawls is that they both take subjective freedom, the freedom of individuals to freely choose what to do and how to live, to be one of the defining elements of a just state. Hegel takes subjective freedom to be a distinctively modern phenomenon. Through a complex and comprehensive historical process, Hegel argues, individual freedom has gradually emerged as an important political, moral, and social value-a value which has become embodied in and made concrete through existing social institutions and practices. ${ }^{62}$ For Hegel, a modern state which does not respect the right of subjective freedom, which does not enable and secure individual freedom, is not, indeed cannot be, just. Rawls agrees with Hegel on this point. According to Rawls, any account of justice must include and incorporate the right of subjective 
freedom at a very basic level. Rawls' first principle of justice thus states that: "Each person is to have an equal right to the most extensive system of equal basic liberties compatible with a similar system of liberty for all.” ${ }^{63}$ All other possible principles of justice are subordinate to this basic principle of justice, and have to be justified in the light of the basic claim of equal freedom embodied in this principle.

A final important parallel between Hegel and Rawls is that they both reject the attempt to justify the basic principles of a state on an abstract ideal. They eschew the impulse to develop a utopian conception of a perfect society, against which to evaluate and criticize existing social institutions. The starting point of political philosophy for both Hegel and Rawls is society as it is, that is, the values and norms embodied and made concrete in the form of actually existing social structures and modes of thought. For both Hegel and Rawls the primary purpose of political philosophy is to explicate the meaning and implications of these values; to elucidate how and to what extent existing values and norms are related to and cohere with one another; to make explicit the implicit and potential conflicts and contradictions between them; and, importantly, to show how our understanding of such values and norms can be reinterpreted, reformulated, prioritized, and justified, so as to develop a more coherent and systematically-structured conception of the right and the good. ${ }^{64}$

Now let us turn to the differences. The first, and perhaps and most important, point of divergence between Hegel and Rawls concerns their methodological approaches. As previously argued Hegel discusses the problem of motivation and arrives at a liberal-perfectionist version of this problem through an extended, critical analysis of the meaning, conditions and possibility of human freedom. This analysis begins with the most minimal conception of freedom imaginable, namely the classical liberal account of freedom of choice understood as freedom from external constraint. Hegel then proceeds to show how this conception necessarily implies and relies upon 
more complex conceptions of freedom, and on the existence of particular social, political, juridical and economic institutions and structures. The problem of motivation is thus always-already there for Hegel, and the need, both theoretical and practical, to account for and resolve this problem constitutes one of the driving forces behind the Outlines of the Philosophy of Right as a whole.

Rawls on the other hand only arrives at the problem of motivation towards the end of $A$ Theory of Justice, after having first explicated and discussed a specific procedural account of justice employing "the original position" and "the veil of ignorance" as heuristic tools to focus and structure his philosophical reflections. ${ }^{65}$ Though Rawls explicitly acknowledges that this approach cannot completely bracket the question of whether the principles of justice arrived at in the (hypothetical) original position can actually motivate human beings, the problem of motivation does not initially constitute the driving force in Rawls’ argument.

This difference is intimately related to another important point of divergence between Hegel and Rawls, namely their respective conceptions of the importance of freedom of choice. For Rawls, conscious deliberation and choice is a defining characteristic of the just state. Citizens of a just and well-ordered society freely choose (or at least would, if placed in a certain ideal-hypothetical position, freely choose) the basic principles on which their society is founded. This is Rawls' articulation of a basic and essential element of liberal democracy: that citizens both ought to and ought to want to actively and consciously participate in the procedures of political decision-making.

Conscious deliberation and democratic participation is not nearly as important to Hegel as it is to Rawls (and most other contemporary political philosophers for that matter). In fact, Hegel explicitly rejects full-blown democracy as a viable model for how to govern a modern state. ${ }^{66}$ For Hegel, the main point is not that citizens actively choose the customs and laws, which structure their social life, but that they can identify with these customs and laws: 
...they [the state and its laws and powers] ${ }^{67}$ are not something alien to the subject. On the contrary, his spirit bears witness to them as to its own essence, the essence in which he has a feeling of his selfhood, and in which he lives as in his own element which is not distinguished from himself. The subject is thus directly linked to the ethical order by a relation which is closer to identity than even the relation of faith or trust. ${ }^{68}$

As Hegel sees it, the contractualist argument embodies and presupposes precisely those problematic aspects of freedom understood as freedom of choice, which the first part of Outlines of the Philosophy of Right served to undermine and deconstruct. According to Hegel freedom of choice cannot be coherently and meaningfully conceived in abstraction from the social, cultural and economic structures in and through which freedom is realized. Any attempt to do so, overlooks the fact that a choice must have some concrete, substantial content. ${ }^{69}$

This difference leads to another crucial difference between Hegel's and Rawls' developmental solutions to the problem of motivation, namely their divergent views on social contract theories. Hegel explicitly rejects contractualist arguments because they cannot account for how choices made by individuals in the state of nature acquire concrete content. According to social contract theorists, choices in the state of nature derive from and are motivated by whatever natural needs and desires govern behaviour in these pre-political circumstances. But, Hegel argues, such a conception of choice provides a poor conception of human freedom. For Hegel the freedom of choice which social contractualists envisions as possible for individuals in a state of nature is simply a form of external determination of human choice by and through natural, non-chosen desires and wants. Echoing Rousseau, Hegel therefore claims that this would be a condition "in which the spirit is submerged in nature and so would be one of savagery and unfreedom."70 
By contrast, Rawls explicitly embraces the contractual argument and notes that his own theory can be viewed as a conscious attempt to "present a conception of justice which generalizes and carries to a higher level of abstraction the familiar theory of the social contract as found, say, in Locke, Rousseau, and Kant." ${ }^{71}$ In contrast to Hegel, Rawls does not invoke the social contractual argument only to dismiss it. Rawls developmental account of how human beings come to identify with the basic principles of a just society in the third part of $a$ Theory of Justice does not, and is not intended to, alter or fundamentally transform our understanding of the arguments put forward in the first two parts of the book.

In fact, the explicit purpose of Rawls' developmental discussion in the third part of A Theory of Justice is simply to strengthen the conclusions already arrived at through the contractual approach developed in part one and two of the book. Part three of A Theory of Justice responds to the practical challenge raised by the problem of motivation, but does so within the contractual framework of the original position. For Rawls, the argument that living in a just and well-ordered society provides the necessary motivational resources for people to gradually acknowledge and identify with the basic principles of justice is primarily a psychological or sociological point, not a philosophical one. It does not fundamentally challenge or expand the understanding of freedom formulated and defended in the first two parts of A Theory of Justice.

The important point for Hegel, on the other hand, is exactly to investigate the requirements and conditions embedded in the very concept of freedom itself. ${ }^{72}$ Rawls' account of the problem of motivation emphasizes the importance of explicating a set of basic principles that can be endorsed by all members of a democratic society. Hegel on the other hand argues that the defining element of the modern state is not whether its citizens consciously endorse a certain set of or norm principles, nor is it the explicit exercise of freedom of choice which these principles make possible. What matters is rather the state's ability to concretely realize the universal aspects of individual freedom 
at a social and institutional level. Hegel insists that it is only in and through the modern state that individuals can become truly free and able to freely choose for themselves how to live and what to do with their lives. Whether this involves that the individual consciously chooses to adopt and endorse the basic principles of justice is of minor importance for Hegel.

For Rawls on the other hand, it is crucial that citizens consciously reflect upon and endorse the basic principles of justice of the society in which they live. It is not enough that the norms and customs of the state become an integral part of each individual's self-understanding; citizens must also actively and consciously choose the basic principles of the state. This is part and parcel of Rawls' commitment to the basic tenets of liberal democracy, and marks a very important point of divergence between Hegel and Rawls approach to the problem of motivation.

\section{Conclusion}

The problem of motivation provides a lens through which to approach and analyze a number of basic and important questions within political and legal philosophy. Our hope is that the discussion in this paper has shown how different approaches to and understandings of this problem leads to different conceptions of justice. In particular, we hope to have drawn attention to an important but often overlooked connection between Rawls' contractualist position in A Theory of Justice and Hegel's liberal-perfectionist position in Outlines of the Philosophy of Right .

Rawls' solution to the problem of motivation seems to be (if not directly indebted to then at least) in surprising accordance with the developmental solution to the problem of motivation formulated by Hegel. For both authors the only consistent way to (re)solve the problem of motivation is through a developmental approach in which being a citizen of a just and well-ordered society is viewed as the result of a gradual developmental process. This process transforms the basic 
motivational make-up of the citizens in such a way that individual self-interest and the (potentially universal) legal and moral requirements of the political community are gradually integrated and ultimately converge.

However, it is important not to mistake these important argumentative parallels for a basic similarity between the two authors' fundamental philosophical projects. Both philosophers want to solve the problem of motivation, but they approach this problem in quite different ways and provide somewhat different responses. Employing the distinctions developed in the first section of this paper we can say that although Rawls believes freedom to be of intrinsic value he seems to approach the problem of motivation primarily from an instrumental-normative perspective, in so far his solution seems to be directly motivated by the need for an answer to the practical problem of social stability. Hegel's account on the other hand is much more ambitious since it not only aims to solve the instrumental-normative problem of social stability, but also provides a liberal-perfectionist account of how human freedom can and should be realized in the world. ${ }^{73}$ Hegel's approach to the problem of motivation thus draws on both the instrumental-normative and the full normative version of this problem to arrive at a liberal-perfectionist solution.

This difference between Hegel's and Rawls' treatment of the problem of motivation illustrates the depth and the variability of the problem of motivation. It is not simply or solely a practical or sociological problem of how to ensure the stability of a given moral and/or political order. It is a problem, which arises as soon as we formulate conceptions of human freedom and ponder the character of the human will. The problem of motivation thus both presupposes and implies deep and abiding philosophical questions; questions that can help us explicate and further develop our understanding of the concept of justice. 
Banerjee, K. and Bercuson, J. (2015) Rawls on the embedded self: Liberalism as an affective regime. European Journal of Political Theory, Vol. 14(2), pp. 209-228.

Bercuson, Jeffrey (2014) John Rawls and the History of Political Thought: The Rousseauvian and Hegelian Heritage of Justice as Fairness. New York: Routledge.

Bøyum S. (2012) Rawls’s notion of the political conception as educator. European Journal of Political Theory, Vol 12(2), pp. 136-152.

Hartz E. and Nielsen C. F. (2015) From conditions of equality to demands of justice: equal freedom, motivation and justification in Hobbes, Rousseau and Rawls. Critical Review of International Social and Political Philosophy 18 (1) pp. 7-25.

Hartz E. and Nielsen C. F. (2014) Freedom, Subjectivity, and the State in Hegel's Philosophy of Right. In: Schmidt C, Mack M and German AR (eds) Post-subjectivity. Cambridge: Cambridge Scholars Publishing, pp. 201-220.

Hegel G. W. F. and Knox T. M. (translator) (2008) Outlines of the Philosophy of Right, Houlgate S. (ed) Oxford World's Classics. Oxford: Oxford University Press.

Hobbes T. (1985) Leviathan, Macpherson CB (ed). London: Penguin Books.

Honneth A. (2013) Das Recht der Freiheit. Grundriß einer demokratischen Sittlichkeit. Berlin: Suhrkamp.

Houlgate S. (2001) Hegel, Rawls and the Rational State. In: Williams R. (ed) Beyond Liberalism and Communitarianism: Studies in Hegel's Philosophy of Right. Albany: SUNY Press.

Laborde C. (2002) The Reception of John Rawls in Europe. European Journal of Political Theory 1(2): 133-146. 
Locke J. (1988) Two Treatises on Government. In: Laslett P. (ed) Cambridge Texts in the History of Political Thought. Cambridge: Cambridge University Press.

Neuhouser F. (2008) Hegel's Social Philosophy. In: Beiser F. C. (ed) The Cambridge Companion to Hegel and Nineteenth-Century Philosophy Cambridge: Cambridge University Press, pp. 204-229.

Plato and Lee H. D. P. (translation and ed) (1974) The Republic. Penguin Classics, London: Penguin Books.

Prichard H. A. (1912) Does Moral Philosophy Rest on a Mistake? Mind 21(81): 21-37.

Rawls J. (1999) A Theory of Justice, Revised Edition. Oxford: Oxford University Press.

Rousseau, Jean-Jacques (1997): The Social Contract, pp. 39-152 in The Social Contract and other later political writings, ed. and tr. Victor Gourevitch, Cambridge University Press, Cambridge, UK

Sandel, M. (1982) Liberalism and the Limits of Justice. Cambridge, Cambridge University Press.

Schwarzenbach S. (1991) Rawls, Hegel, and Communitarianism. Political Theory 19(4): 539-571.

\footnotetext{
${ }^{1}$ One of the earliest formulations can be found in Book One and Two of Plato's The Republic for an early formulation of the problem. Plato, 1974 pp. 327-367.

2 Thanks to Jeppe von Platz for providing us with an early formulation of the following distinctions.

${ }^{3}$ Houlgate, 2001 and Laborde, 2002 constitute rare exceptions to this general rule.

${ }^{4}$ An extreme version of this position is the anarchical position, where the legitimacy of the political authority of the state has to be rationally justified to someone who is not yet a member of the state. This is where Nozick begins his argument in Anarchy State and Utopia (Nozick 1974). See especially "Part 1: State-of-Nature Theory, or How to Back into a State without Really Trying” (pp. 1-146). It is also here the classical contract theories (Hobbes, Locke and Rousseau) take their starting point.

${ }^{5}$ For the classical formulation of this distinction see Prichard 1912. Prichard does not explicitly discuss the problem of motivation. His primary interest is the distinct but structurally similar question "Why be moral?" or "Why be virtuous?" However Prichard's basic point, that these questions are inherently ambiguous and can be approached in at least two distinct ways, seems equally applicable to the problem of motivation.

${ }^{6}$ This is how Hobbes frames the problem in Leviathan. See Hobbes 1985, ch. 13-15. See also Hume 1975, Book II, Sect. IX, pt. II, p. 280. David Gauthier have proposed an updated version of Hobbes' basic position in the form of a rational choice based moral theory. See Gauthier 1986.
} 
${ }^{7}$ This question is the starting-point from which Nozick develops the rights-based libertarian position formulated in Anarchy State and Utopia. See in particular Nozick 1974, "Preface" and "Chapter 1. Why State-of-Nature Theory?"

${ }^{8}$ See e.g. Prichard for two different ways to answer the "Why be moral?" question: One focuses on the individual's happiness, the other on the (inherent) goodness of moral action (Prichard, 1912 p. 22).

${ }^{9}$ Explaining the social cohesion of modern societies, including the apparent willingness of most citizens to obey the basic moral and juridical rules of society, was one of the problems which inspired the establishment of modern sociology. See in particular Durkheim 1984, "Preface to the second edition” (pp. xxxi-lix), “Introduction” (pp. 1-8), Book III (pp. 289-328) and "Conclusion" (pp. 329-341). See Durkheim 1982 ch. 2-3 for a functionalist account of the role of crime and punishment in creating social cohesion.

${ }^{10}$ This, as we shall soon see, is the position of Rawls and, to some extent, Hegel. See our comparative discussion of Rawls and Hegel at the end of the paper.

${ }^{11}$ Once again Hegel and Rawls both seem to subscribe to something like this position. Their differences will be discussed in the concluding sections of this paper.

12 This understanding of freedom is sometimes articulated as "positive" or "reflective freedom" in contrast with "negative freedom" or as "freedom as absence from external constraints". See Berlin 1969 for a classical discussion of this distinction. See Honneth 2013 pp. 58 for a discussion of recent literature on the concept of "positive" or "reflective freedom.”

${ }^{13}$ Joseph Raz is perhaps the most prominent contemporary proponent of liberal perfectionism. See Raz 1986 and 19

${ }^{14}$ See e.g. Hobbes, 1985 ch. 13-18 and Rawls’ discussion of Hobbes in Rawls 1999, § 38, 42 and 76.

${ }^{15}$ Hobbes 1985, ch. 13, p. 188.

${ }^{16}$ Ibid. ch. 13-17.

${ }^{17}$ Ibid. ch. 17, p. 227.

${ }^{18}$ See e.g. Locke, 1988, Book II, Ch. VII-IX.

${ }^{19}$ Locke, 1988, Book II, Ch. VII, pp. 318-323.

${ }^{20}$ The developmental approach thus includes a commitment to some kind of political education. For a thorough discussion of Rawls' views on political education see Bøyum 2012.

${ }^{21}$ We have borrowed the terms "personal freedom," "moral freedom” and "social freedom” from Neuhouser, 2008.

${ }^{22}$ Hegel, 2008, § 15. All references to Hegel's Outlines of the Philosophy of Right will be to paragraph numbers in this work. Hegel's remarks (Anmerkungen) to these paragraphs are indicated by "A" and his additions (Zusätze) by "Z".

${ }^{23}$ Hegel, 2008, § 35. As Neuhouser explains: "Persons are conceived of as possessing a set of given drives and desires that have the capacity to motivate them to act, but they are persons in virtue of the fact that they are not determined to act on the drives and desires they happen to have" (Neuhouser, 2008, p. 206).

${ }^{24}$ Hegel 2008, § 41-81.

${ }^{25}$ Ibid. § 82-104.

${ }^{26}$ Ibid. § 34-40.

${ }^{27}$ Ibid. § 104.

${ }^{28}$ Ibid. § 135 A.

${ }^{29}$ Ibid. § 260.

${ }^{30}$ Ibid. § 141.

${ }^{31}$ Ibid. § 158.

${ }^{32}$ Ibid. § $158 \mathrm{Z}$.

${ }^{33}$ Ibid. § 201.

${ }^{34}$ Ibid. § $190 \mathrm{Z}$ and §191 Z.

${ }^{35}$ Ibid. § 192 Z.

${ }^{36}$ Ibid. § 183.

${ }^{37}$ Ibid. § 260.

${ }^{38}$ Ibid. § 260.

${ }^{39}$ Ibid. § 258 A

${ }^{40}$ Ibid. § 258 and 258 A.

${ }^{41}$ Ibid. § $258 \mathrm{~A}$.

${ }^{42}$ Laborde, 2002 p. 133. See also Sandel 1983, in particular the Introduction and ch. 1.

${ }^{43}$ Rawls, 1999, § 76.

${ }^{44}$ Or at least the Rawls who wrote $A$ Theory of Justice.

${ }^{45}$ Rawls 1999, § 3.

${ }^{46}$ Ibid. § 69.

${ }^{47}$ Ibid.

${ }^{48}$ Ibid. § 76. 
${ }^{49}$ Ibid. $§ 70$.

50 Ibid. $\S 76$.

${ }^{51}$ Ibid. § 70.

52 Ibid.

${ }^{53}$ Rawls, 1999, § 71.

54 Ibid.

${ }^{55}$ Ibid.

56 Ibid.

${ }^{57}$ Ibid. § 72.

58 Ibid.

59 Ibid.

${ }^{60}$ Ibid.

${ }^{61}$ Ibid. § 75.

62 See e.g. Hegel, 2008, § 124 A. See also Hegel, 2008, § 154.

${ }^{63}$ Rawls,1999, § 46. Note that for Rawls this principle has logical as well as lexical priority over his second principle of justice (the difference principle), which concerns the allocation and distribution of primary social goods. This priority means that "the basic liberties can be restricted only for the sake of liberty" i.e. basic liberties cannot be restricted in order to secure a more efficient and equal distribution of welfare, even though such distribution is part and parcel of full-fledged justice.

${ }^{64}$ This is quite easy to see in the case of Hegel. However, Rawls has often been seen as attempting to develop a completely ahistorical and acultural account of political justice. This however is clearly not Rawls’ intention. See e.g. Rawls' discussion of reflective equilibrium in A Theory of Justice $\S 5$ : “... what we shall do is to collect together into one conception a number of conditions on principles that we are ready upon due consideration to recognize as reasonable. These constraints express what we are prepared to regard as limits on fair terms of social cooperation. One way to look at the idea of the original position, therefore, is to see it as an expository device which sums up the meaning of those conditions and helps us to extract their consequences.” See also the "Concluding remarks on Justification” in $\S$ 87.

${ }^{65}$ See Rawls 1999 Part One, in particular § 3, 4 and 11 and § 20-30.

${ }^{66}$ Hegel, 2008, § 272 and 272 A. See also Houlgate 2001.

${ }^{67}$ Hegel, 2008, § 146.

68 Ibid. § 147.

69 Ibid. $\S 6$.

${ }^{70}$ Ibid. § 194 A. See Rousseau 1997, Book 1, Ch. 8.

${ }^{71}$ Rawls 1999, § 3.

${ }^{72}$ Hartz and Nielsen 2014, p. 215.

${ }^{73}$ In A Theory of Justice Rawls acknowledges the psychological attractiveness of perfectionism (Rawls 1999, § 72, p. 217), but rejects perfectionism as a basic political principle, since it seems to define the right in terms of the good, not the good in terms of the right (Rawls 1999, § 50, pp. 285-292). Rawls' rejection of perfectionism also seems to have been one of the primary motivations behind the subsequent developments of his theory, which ultimately resulted in the publication of Political Liberalism. See Nussbaum 2011 for an extended discussion of Rawls’ rejection of liberal perfectionism and his endorsement of a (relatively thin and normatively minimal) form of political liberalism instead. 